ARTIKEL PENELITIAN

\title{
Hubungan Status Imunisasi Dasar terhadap Pneumonia pada Pasien Balita Rawat Inap di RSIA Respati Tasikmalaya
}

\author{
Noufal Rizqullah, ${ }^{1}$ Zulmansyah, ${ }^{2}$ Mirasari Putri ${ }^{3}$ \\ ${ }^{1}$ Prodi Sarjana Kedokteran, Fakultas Kedokteran Universitas Islam Bandung \\ ${ }^{2}$ Departemen Biokimia, Gizi, Biomolekuler, Fakultas Kedokteran Universitas Islam Bandung \\ ${ }^{3}$ Departemen Ilmu Kesehatan Anak, Fakultas Kedokteran Universitas Islam Bandung
}

\begin{abstract}
Abstrak
Pneumonia adalah penyakit inflamasi pada paru yang merupakan salah satu penyebab kematian anak di dunia. Salah satu faktor risiko pasti pneumonia adalah status imunisasi dasar yang belum lengkap. Imunisasi yang mencegah pneumonia seperti imunisasi Pneumococcal conjugate vaccine (PCV), Haemophilus influenze tipe B (Hib), DifteriPertusis-Tetanus (DPT), dan campak. Tujuan penelitian ini adalah mengetahui hubungan status imunisasi dasar $<1$ tahun dengan pneumonia pada pasien balita rawat inap di RSIA Respati Tasikmalaya. Penelitian ini menggunakan metode observasional analitik dengan pendekatan kasus kontrol periode Oktober - November 2020. Sampel diambil dengan teknik non-random dengan jenis kuota sampling. Data status imunisasi diperoleh dari rekam medis pasien dan Kartu Menuju Sehat sebagai kontrol. Analisis data menggunakan uji chi-square. Hasil penelitian didapatkan seluruh balita tidak pernah mendapatkan imunisasi PCV, 22 dari 30 balita mendapatkan imunisasi Hib lengkap, 25 dari 30 balita mendapatkan imunisasi DPT lengkap, dan 27 dan 30 balita pernah mendapatkan imunisasi campak. Hasil analisis menunjuk hubungan status imunisasi Hib, DPT, dan campak (nilai $\mathrm{p}=0,000$ ). Balita yang mendapatkan imunisasi Hib, DPT, dan campak lengkap memiliki peluang lebih baik terhindar dari pneumonia dibanding dengan balita yang belum pernah mendapatkan imunisasi. Diharapkan masyarakat mendapat imunisasi Hib, DPT, dan campak lengkap untuk mencegah pneumonia.
\end{abstract}

Kata kunci: Balita, pneumonia, Status imunisasi

\section{Relationship of Basic Immunization Status to Pneumonia in Under-five years Children at RSIA Respati Tasikmalaya}

\begin{abstract}
Pneumonia is an inflammatory disease of the lungs, which is one of the primary causes of death in children worldwide. One of the definite risk factors of pneumonia is incomplete immunization status. Immunizations that prevent pneumonia are Pneumococcal conjugate vaccine (PCV), type B Haemophilus influenze (Hib), DiphteriaPertussis-Tetanus (DPT), and measles immunization. This study aimed to determine the relationship between basic immunization status <1-year-old with pneumonia in under-five hospitalized patients at RSIA Respati Tasikmalaya in 2020. This was a case-control study. That conducted in October - November 2020 on 30 hospitalized under-five children at Mother and Child Hospital Respati Tasikmalaya and 30 healthy under-five children as a control group. Samples were taken using a quota sampling technique. Retrieval of immunization status using patient medical records and Maternal and Neonatal Health Book. Data analysis using the chi-square test. The results showed that all children under five had never received PCV immunization, 22 from 30 children received complete Hib immunization, 25 from 30 children received complete DPT immunization, and 27 from 30 children received measles immunization. Chi-square analysis showed that there is a correlation between Hib, DPT, and measles immunization status with pneumonia in under-five children $(p$-value $=0.000)$. Under-five children who had received complete Hib, DPT, and measles immunization have a better chance to avoid pneumonia compared to those who had never received immunization. It is hoped that people received complete Hib, DPT, and measles immunization to prevent pneumonia.
\end{abstract}

Keywords: Immunization status, pneumonia, under-five children

Received: 8 ...; Revised: ...; Accepted: ...; Published: ...

Koresponden: Noufal Rizqullah. Program Pendidikan Sarjana Kedokteran Fakultas Kedokteran Universitas Islam Bandung. Jl. Taman Sari No.22, Kota Bandung, Provinsi Jawa Barat. Telepon :085323828555. Email: noufalrizqullah@gmail.com 


\section{Pendahuluan}

Pneumonia adalah penyakit inflamasi pada paruparu akibat agen infeksi seperti bakteri, virus, atau jamur. ${ }^{1}, 2$ Streptococcus pneumoniae adalah bakteri penyebab utama pneumonia pada balita di seluruh negara berkembang. 3 Pneumonia merupakan salah satu penyebab kematian anak-anak di dunia. Sekitar 16 \% kematian pada balita disebabkan oleh penyakit ini, terutama di negara-negara Asia Tenggara. ${ }^{4}$ Riskesdas tahun 2018 menunjukan adanya peningkatan prevalensi pneumonia pada balita menjadi $2 \%$. Di Jawa Barat adanya peningkatan prevalensi pneumonia menjadi 2,6\%.5 Menurut Profil Kesehatan Jawa Barat tahun 2017, cakupan pneumonia di 26 kabupaten dan kota di Jawa Barat masih di bawah target 80\% dengan Kabupaten Tasikmalaya sebesar $24,8 \% .^{6}$

Tingginya angka mortalitas pneumonia pada balita di dunia disebabkan oleh berbagai faktor risiko. Faktor risiko pneumonia terdiri dari pejamu (Host), penyebab (Agent), dan lingkungan (Environtment). Salah satu faktor risko manusia adalah status imunisasi tidak lengkap. ${ }^{7}$ Faktor risiko pneumonia pada balita juga meliputi faktor risiko pasti (Definite), faktor risiko hampir pasti (Likely), dan faktor risiko mungkin (Possible). Faktor risiko pasti (Definite) sebagian besar buktinya konsisten menunjukan faktor risiko, salah satunya adalah tidak diimunisasi campak pada 12 bulan pertama. 8

Status imunisasi dasar yang belum lengkap banyak ditemukan pada anak yang menderita pneumonia. Imunisasi yang mencegah pneumonia adalah imunisasi pneumokokus dan Haemophilus influenza tipe B untuk mencegah infeksi patogen langsung, serta imunisasi pertussis dalam DPT dan campak untuk mencegah pneumonia sebagai komplikasi penyakit sebelumnya, termasuk dalam imunisasi dasar $<1$ tahun. ${ }^{8},{ }^{9}$ Menurut Riskesdas 2018, di Indonesia cakupan imunisasi dasar lengkap pada anak umur 12-23 bulan sebesar 57,9\% yang sebelumnya sebesar $59,2 \%$ pada tahun $2013 .{ }^{5}$ Menurut Profil Kesehatan Indonesia tahun 2018 di Jawa Barat, cakupan imunisasi dasar lengkap pada bayi sebesar 96,6\% dan sudah mencapai target Renstra yaitu 95,2\%, namun cakupan imunisasi campak di Jawa Barat tahun 2018 sebesar 92,8\% yang seharusnya mencapai target Renstra yaitu 95\%.10

Anak beresiko 2,39 kali lebih besar terkena pneumonia bila tidak mendapatkan status imunisasi lengkap. ${ }^{11}$ Penelitian menunjukan balita beresiko 3,21 kali terkena pneumonia tidak mendapatkan imunisasi campak dan beresiko 2,34 kali terkena pneumonia bila tidak mendapatkan imunisasi DPT. ${ }^{12}$ Balita dengan status imunisasi dasar lengkap tanpa Hib berpeluang lebih tinggi 1,27 kali terkena pneumonia. ${ }^{13}$ Imunisasi PCV10 pada anak dapat mencegah penumonia bakteri sebesar 22\%.14

Berbagai penelitian telah banyak melakukan penelitian tentang imunisasi DPT dan campak pada pneumonia, namun penelitian tentang imunisasi PCV dan Hib masih jarang dilakukan. Penelitian ini bertujuan untuk mengetahui hubungan antara status imunisasi dasar $<1$ tahun yang meliputi imunisasi PCV, Hib, DPT, dan campak dengan imunisasi Pneumonia Balita.

\section{Metode}

Subjek penelitian ini adalah 6o balita terbagi menjadi dua grup yaitu 30 balita yang didiagnosis pneumonia di RSIA Respati Tasikmalaya dan 30 balita kontrol. Data penelitian didapat dari data rekam medis periode bulan Januari tahun 2019 sampai bulan September tahun 2020 untuk kelompok kasus dan buku KIA dengan periode yang sama untuk kelompok kontrol. Kriteria kelompok kasus adalah balita usia 12-59 bulan, sudah mendapatkan imunisasi dasar $<1$ tahun, didiagnosis mengidap pneumonia komunitas. Kriteria kelompok kontrol adalah balita sehat. Kelompok kasus didapatkan pasien balita rawat inap di RSIA Respati Tasikmalaya dan kelompok kontrol didapatkan dari Posyandu Desa Sukaherang, Desa Neglasari, dan Desa Sukarame.

Prosedur penelitian dilakukan penentuan diagnosis pneumonia pada rekam medis, kemudian penentuan status imunisasi pada rekam medis dan Kartu Menuju Sehat pada Buku KIA dan dilakukan interpretasi status imunisasi, kemudian untuk status gizi dilakukan plotting dengan menggunakan growth chart dari WHO berdasarkan berat badan/usia. ${ }^{22,23}$

Penelitian ini menggunakan metode observasional analitik dengan pendekatan case control. Teknik sampling menggunakan sampling kuota. Uji statistik yang dipakai adalah chi-square test menggunakan software SPSS versi 24 data disajikan dalam bentuk tabel distribusi.

\section{Hasil}

Berdasarkan tabel 1, didapatkan 17 dari 30 balita pada kelompok pneumonia berusia 12-23 bulan. Dari 30 balita, 24 balita kelompok kontrol berusia 24-59 bulan. Sebanyak 21 dari 30 balita kelompok pneumonia merupakan laki-laki. Sebanyak 17 dari 30 balita kelompok kontrol merupakan perempuan.

Tabel 1. Karakteristik Umum Subjek Penelitian

\begin{tabular}{ccccc}
\hline & \multicolumn{2}{c}{ Subjek } & \multicolumn{2}{c}{ Total } \\
\cline { 2 - 3 } Variabel & Pneumonia & Kontrol & & \\
\cline { 2 - 4 } & $\mathrm{n}=30$ & $\mathrm{n}=30$ & $\mathrm{n}=60$ & $\%$ \\
\hline Usia Balita & & & & \\
12-23 bulan & 17 & 6 & 23 & 38 \\
24-59 bulan & 13 & 24 & 37 & 61 \\
Jenis Kelamin & & & & \\
Laki-Laki & 21 & 13 & 34 & 56 \\
Perempuan & 9 & 17 & 26 & 43 \\
Status Gizi & & & & \\
Gizi Buruk & 5 & 1 & 6 & 10 \\
Gizi Kurang & 7 & 3 & 10 & 16 \\
Gizi Baik & 18 & 25 & 43 & 71 \\
Gizi Lebih & 0 & 1 & 1 & 1 \\
& & & & \\
\hline
\end{tabular}

Terdapat 18 dari 30 balita kelompok pneumonia mengalami gizi baik, namun didapatkan sebanyak 7 dari 30 balita mengalami gizi kurang dan 5 dari 30 balita mengalami gizi buruk. Sejumlah 24 dari 30 balita kelompok kontrol memiliki gizi yang baik, namun sebanyak 4 dari 30 balita mengalami gizi kurang. 
Tabel 2. Karakteristik Status

\begin{tabular}{|c|c|c|c|c|}
\hline \multirow{3}{*}{$\begin{array}{l}\text { Status Imunisasi } \\
\text { Usia }<1 \text { tahun }\end{array}$} & \multicolumn{2}{|c|}{ Subjek } & \multirow{2}{*}{\multicolumn{2}{|c|}{ Total }} \\
\hline & \multirow{2}{*}{$\begin{array}{c}\text { Pneumonia } \\
\mathrm{n}=30\end{array}$} & \multirow{2}{*}{$\begin{array}{c}\text { Kontrol } \\
\mathrm{n}=30\end{array}$} & & \\
\hline & & & $\mathrm{n}=60$ & $\%$ \\
\hline \multicolumn{5}{|l|}{ Imunisasi PCV } \\
\hline Lengkap & o & o & o & o \\
\hline Tidak Lengkap & o & o & o & o \\
\hline Tidak Pernah & 30 & 30 & 60 & 100 \\
\hline \multicolumn{5}{|l|}{ Imunisasi Hib } \\
\hline Lengkap & 8 & 22 & 30 & 50 \\
\hline Tidak Lengkap & 1 & 8 & 9 & 15 \\
\hline Tidak Pernah & 21 & o & 21 & 35 \\
\hline \multicolumn{5}{|l|}{ Imunisasi DPT } \\
\hline Lengkap & 8 & 25 & 33 & 55 \\
\hline Tidak Lengkap & 1 & 5 & 6 & 10 \\
\hline Tidak Pernah & 21 & o & 21 & 35 \\
\hline \multicolumn{5}{|l|}{ Imunisasi Campak } \\
\hline Pernah & 7 & 27 & 30 & 50 \\
\hline Tidak Pernah & 23 & 3 & 30 & 50 \\
\hline
\end{tabular}

Tabel 2 menunjukan, kedua kelompok tidak pernah mendapatkan imunisasi PCV. Sebanyak 21 dari 30 balita kelompok pneumonia tidak pernah mendapatkan imunisasi Hib. Terdapat 22 dari 30 balita kelompok kontrol didapatkan dengan status imunisasi Hib lengkap. Sebanyak 21 dari 30 balita kelompok pneumonia didapatkan tidak pernah mendapatkan imunisasi DPT. Terdapat 25 dari 30 balita pada kelompok kontrol didapatkan memiliki status imunisasi DPT lengkap. Terdapat 23 dari 30 balita kelompok kasus didapatkan tidak pernah mendapatkan imunisasi campak, dan 7 dari 30 balita pernah mendapatkan imunisasi campak. Sejumlah 3 dari 30 balita kelompok kontrol didapatkan tidak pernah mendapatkan imunisasi campak, dan 27 dari 30 balita pernah mendapatkan imunisasi campak.

Tabel 3. Analisis Bivariat

\begin{tabular}{|c|c|c|c|c|}
\hline \multirow{3}{*}{ Variabel } & \multicolumn{2}{|c|}{ Subjek } & \multirow{3}{*}{$\mathrm{p}$-value } & \multirow{3}{*}{ OR (CI 95\%) } \\
\hline & Pneumonia & Kontrol & & \\
\hline & $\mathrm{n}=30$ & $\mathrm{n}=30$ & & \\
\hline \multicolumn{4}{|l|}{ Imunisasi Hib } & $0,132(0,042-$ \\
\hline Lengkap & 8 & 22 & o,ooob* & $0,415)$ \\
\hline $\begin{array}{l}\text { Tidak Lengkap dan } \\
\text { Tidak Pernah }\end{array}$ & 22 & 8 & & \\
\hline \multicolumn{5}{|l|}{ Imunisasi DPT } \\
\hline Lengkap & 8 & 25 & o,ooob* & o,073 (o,021- \\
\hline $\begin{array}{l}\text { Tidak Lengkap dan } \\
\text { Tidak Pernah }\end{array}$ & 22 & 5 & & $0,255)$ \\
\hline \multicolumn{5}{|l|}{ Imunisasi Campak } \\
\hline Pernah & 7 & 27 & o,oooa* & o,034 (0,008- \\
\hline Tidak Pernah & 23 & 3 & & $0,146)$ \\
\hline \multicolumn{5}{|l|}{ Usia Balita } \\
\hline $12-23$ bulan & 17 & 6 & $0,003 \mathrm{a}^{*}$ & $5,231\left(1,657^{-}\right.$ \\
\hline 24-59 bulan & 13 & 24 & & $16,515)$ \\
\hline \multicolumn{5}{|l|}{ Jenis Kelamin } \\
\hline Laki-Laki & 21 & 13 & $0,037 a^{*}$ & $3,051\left(1,053^{-}\right.$ \\
\hline Perempuan & 9 & 17 & & $8,839)$ \\
\hline \multicolumn{5}{|l|}{ Status Gizi } \\
\hline $\begin{array}{l}\text { Gizi Kurang dan Gizi } \\
\text { Buruk }\end{array}$ & 12 & 4 & o,o39b* & $\begin{array}{c}4,333\left(1,203^{-}\right. \\
15,605)\end{array}$ \\
\hline $\begin{array}{l}\text { Gizi Baik dan Gizi } \\
\text { Lebih }\end{array}$ & 18 & 26 & & \\
\hline
\end{tabular}

Hasil analisis bivariat pada tabel 3. dapat dilihat bahwa terdapat penggabungan hasil ukur tidak lengkap dan tidak pernah pada status imunisasi Hib dan DPT untuk mendapatkan nilai <0,01 dengan fisher exact test, sedangkan status imunisasi campak dapat menggunakan Chi-square test dan didapatkan nilai <0,01. Status imunisasi Hib, DPT, dan campak menunjukan ada hubungan yang sangat bermakna dengan OR berurutan 0,132 (CI 95\%: 0,042-0,415); o,073 (CI 95\%: 0,021-0,255); 0,034 (CI 95\%: o,008$0,146)$.

Usia dan jenis kelamin dapat menggunakan Chisquare test dan didapatkan nilai <0,05. Terdapat penggabungan hasil ukur gizi buruk dan gizi lebih pada status gizi untuk mendapatkan nilai <0,05 dengan fisher exact test. Usia, jenis kelamin, dan status gizi menunjukan adanya hubungan yang bermakna dengan OR berurutan 5,231 (1,657-16,515); 3,051 (1,0538,839); 4, 333 (1,203-15,605)

\section{Pembahasan}

Penelitian ini menunjukan bahwa terdapat hubungan yang bermakna pada status imunisasi Hib, DPT, dan Campak dengan pneumonia pada balita di RSIA Respati Tasikmalaya tahun 2020. Pada penelitian ini, data status imunisasi PCV tidak dapat dilakukan analisis bivariat karena kedua kelompok tidak pernah

melakukan imunisasi PCV. Imunisasi PCV tidak termasuk pada imunisasi wajib yang diselenggarakan oleh pemerintah Indonesia, sehingga kedua kelompok tidak pernah mendapatkan imunisasi PCV.

Hasil uji Chi Square status imunisasi Hib menunjukan nilai <0,01 dengan nilai OR 0,132 (CI 95\%: 0,042-0,415) sehingga menunjukan adanya hubungan status imunisasi Hib periode usia $<1$ tahun dengan pneumonia pada balita. Hasil ini sesuai dengan penelitian Benedika I. dkk tahun 2017, menyatakan ada hubungan yang signifikan antara status imunisasi Hib dalam DPT-HB-Hib dengan pneumonia pada balita dan didapatkan nilai $\mathrm{OR}=3,946$ (95\%; CI 1,3811,27), sehingga balita dengan status imunisasi Hib tidak lengkap berisiko 3,946 kali terkena pneumonia daripada balita dengan status imunisasi Hib lengkap.15 Haemophilus influenza Tipe B merupakan penyebab kedua tersering pneumonia seteleah Streptococcus pneumoniae. ${ }^{1}$

Pada penelitian ini, status imunisasi DPT dan Campak menunjukan nilai <0,01 dengan nilai OR berurutan 0,073 (CI 95\%: 0,021-0,255); 0,034 (CI 95\%: 0,008-0,146) sehingga menunjukan adanya hubungan sangat bermakna status imunisasi DPT dan Campak periode usia <1 tahun dengan pneumonia pada balita. Hasil ini sesuai dengan penelitian Puspita S. dan Vitawati tahun 2015, menyatakan adanya hubungan status imunisasi DPT dan Campak dengan pneumonia pada balita, serta mendukung hasil penelitian sebelumnya oleh Hartati S. dkk tahun 2012 yang menyatakan ada hubungan antara riwayat pemberian imunisasi DPT dan Campak pada balita dengan kejadian pneumonia.12,16 Imunisasi 
DPT dapat mencegah anak terkena penyakit difteri, pertusis, dan tetanus. Pneumonia dapat disebabkan oleh komplikasi penyakit pertusis. ${ }^{16}$ Toksin pertusis bekerja pada makrofag alveolar, mempengaruhi jalur kemokin dan sitokin, dan menghambat respon imun bawaan manusia, sehingga rentan terhadap infeksi sekunder seperti virus influenza, yang merupakan salah satu penyebab pneumonia pada usia 4 bulan -5 tahun. 16,17 Pneumonia adalah komplikasi campak yang paling umum, dapat disebabkan oleh virus campak sendiri, infeksi sekunder virus lainnya seperti adenovirus, atau infeksi sekunder bakteri. Imunosupresi sementara dapat terjadi selama infeksi virus campak, menyebabkan hipersensitivitas tipe tertunda dan penurunan jumlah sel-T, sehingga meningkatkan risiko infeksi bakteri sekunder.18,19 Pemberian imunisasi campak pada diharapkan anak terhindar dari penyakit campak yang bisa mengalami komplikasi penyakit pneumonia. ${ }^{16}$

Pada penelitian ini menunjukan karakteristik pasien pneumonia lebih banyak pada kelompok balita usia 12-23 bulan. Hal ini sejalan dengan penelitian Itma A. dkk, tahun 2012 yang menemukan adanya pasien pneumonia lebih banyak pada usia <24 bulan. ${ }^{11} \mathrm{Hal}$ ini disebabkan saluran pernapasan yang relatif sempit dan imunitas yang belum sempurna, balita memiliki mekanisme pertahanan yang masih rendah daripada orang dewasa. ${ }^{12}$

Karakteristik pasien pneumonia penelitian ini lebih banyak pada laki-laki daripada perempuan. Hal serupa ditemukan pada penelitian Lisa A. dkk tahun 2012, mendapatkan pneumonia didominasi oleh lakilaki. Hal ini dapat dipengaruhi oleh diameter saluran pernapasan yang lebih sempit anak balita laki-laki daripada perempuan atau kemungkinan perbedaan ketahanan tubuh yang dipengaruhi kromosom seks. ${ }^{20}$

Status gizi kurang pada pasien pneumonia ditemukan lebih banyak daripada status gizi kurang pada balita sehat. Temuan ini serupa dengan penelitian Lisa A. dkk tahun 2012, menunjukan balita pneumonia dengan status gizi kurang lebih banyak daripada balita bukan pneumonia dengan status gizi kurang. ${ }^{20}$ Balita yang memiliki status gizi kurang berisiko terjadi pneumonia sebesar 6,52 kali daripada balita yang berstatus gizi baik. ${ }^{12}$ Gizi kurang dapat menyebabkan penurunan jumlah IgA sekretori, sistem komplemen, dan sel mediator imun, sehingga menurunkan sistem imun humoral. Terjadi gangguan pada regenerasi epitel respirasi. Kelenjar Timus dan Tonsil akan atrofi sehingga menurunkan jumlah sel $\mathrm{T}$ limfosit secara bertahap. Hal ini dapat menurunkan sistem imun selular yang membuat proses infeksi lebih mudah untuk berlanjut. ${ }^{21}$

\section{Simpulan}

Terdapat hubungan antara status imunisasi Hib, DPT, dan Campak <1 tahun terhadap pneumonia pada balita.

\section{Ucapan Terimakasih}

Peneliti menyampaikan ucapan terima kasih dan juga apresiasi kepada seluruh pimpinan, jajaran, dan staff Fakultas Kedokteran Universitas Islam Bandung, pihak RSIA Respati Tasikmalaya, serta Puskesmas Sukarame Kabupaten Tasikmalaya

\section{Pertimbangan Masalah etik}

Penelitian ini sudah mendapat persetujuan etik oleh Komite Etik Penelitian Kesehatan Fakultas Kedokteran Universitas Islam Bandung dengan nomor: nomor: 027/KEPK-Unisba/X/2020.

\section{Daftar Pustaka}

1. Thomas J. Marrie. Acute Bronchitis and Community-Aquired Pneumonia. Dalam: Michael AG, Jack AE, Robert MK, Allan IP, Jay AF, Robert MS, penyuting. Fishman's Pulmonary Diseases and Disorders, 5thEd. Vol. 14. 2015.

2. Sattar SBA, Sharma S. Bacterial Pneumonia. [Updated 2020 Nov 21]. In: StatPearls [Internet]. Treasure Island (FL): StatPearls Publishing; 2020 Jan-. Available from: https://www.ncbi.nlm.nih. gov/books/NBK513321/

3. The United Nations Children's Fund /World Health Organization. Pneumonia The Killer of Children. The United Nations Children's Fund (UNICEF)/World Health Organization (WHO). 2006. 1-44 p.

4. who.int.[website on the Internet] World Pneumonia Day 2018 [updated 2018; diunduh 16 Desember 2019]. Tersedia dari: www.who.int. 2018.

5. Riskesdas K. Hasil Utama Riset Kesehatan Dasar (RISKESDAS). J Phys A Math Theor [Internet]. 2018;44(8):1-200. Available from: http://arxiv. org/abs/1011.1669\%oA

6. Profil Kesehatan Jawa Barat. Profil Kesehatan Jawa Barat 2017. 2017;1-236.

7. Hartati S. Analisis Faktor Risiko Yang Berhubungan Dengan Kejadian Pneumonia Pada Anak Balita. Thesis. 2011;14-152.

8. Rudan I, Boschi-Pinto C, Biloglav Z, Mulholland K, Campbell H. Epidemiology and etiology of childhood pneumonia. Bull World Health Organ. 2008;86(5):408-16.

9. IDAI.or.id [website on the internet]. Melengkapi/ Mengejar Imunisasi (Bagian I) [updated 2015 May 30; diunduh 13 Januari 2021]. Tersedia dari: www.idai.or.id

10. Kemenkes RI. Profil Kesehatan Indonesia 2018, Kementerian Kesehatan RI, Jakarta. 2018. 207 p.

11. Itmah A, Rasdi N, Jumriani A. Faktor Risiko Kejadian Pneumonia Anak Umur 6-59 Bulan di RSUD Salewangan Maros Tahun 2012 Bagian Epidemiologi Fakultas Kesehatan Masyarakat Universitas Hasanuddin Mak. 2012;1-14.

12. Hartati S, Nurhaeni N, Gayatri D. Faktor Risiko Terjadinya Pneumonia pada Anak Balita. J Keperawatan Indones. 2012;15(1):13-20. 
13. Soleman R, Nilapsari R, Nurhayati E. Hubungan Kejadian Pneumonia Balita dengan Status Imunisasi Dasar Lengkap disertai Vaksinasi Haemophilus Influenzae type B di RSUD Al-Ihsan Kabupaten Bandung Periode Tahun 2015. 2015;16.

14. le Roux DM, Zar HJ. Community-acquired pneumonia in children - a changing spectrum of disease. Pediatr Radiol. 2017;47(11):1392-8.

15. Iswari BM, Nurhidayah I, Hendrawati S. Hubungan Status Imunisasi: DPT-HB-HIB dengan Pneumonia pada Balita Usia 12-24 bulan di Puskesmas Babakan Sari Kota Bandung. J Keperawatan. 2017;8(2):101-15.

16. Sari P, Vitawati. Hubungan Pemberian Imunisasi DPT Dan Campak Terhadap Kejadian Pneumonia Pada Anak Usia 10 Bulan - 5 Tahun di Puskesmas Sangurara Kota Palu Tahun 2015. J Ilm Kedokt. 2019;6(1):45-54

17. N.Rahajoe N, Supriyanto B, Setyanto DB. Buku
Ajar Respirologi Anak. Badan Penerbit Ikat Dr Anak Indones. 2018;(1):10-47.

18. Perry RT, Halsey NA. The clinical significance of measles: A review. J Infect Dis. 2004;189(SUPPL. 1).

19. Leah TB, Mayra EL, Andrea LP, Susan MS, Karen W. Exanthematous Viral Diseases. Dalam: Lowell AG, Stephen IK, Barbara AG, Amy SP, David JF, Klaus W, penyunting. Fitzpatrick's Dermatology in General Medicine 8th ed. United States: McGrawHill; 2012. hlm 2339.

20. Garina LA, Putri SF, Yuniarti. Hubungan Faktor Risiko dan Karakteristik Gejala Klinis dengan Kejadian Pneumonia pada Balita. 2012;26-32.

21. Wicaksono H. Nutritional Status Affects Incidence of Pneumonia in Underfives. Folia Medica Indones. 2016;51(4):285.

22. WHO. WHO child growth standards for boys. Who. 2010;

23. WHO. WHO child growth standards for girls. Who. 2010; 